\title{
IMPLEMENTASI MANAJEMEN STRATEGIS DALAM UPAYA \\ PENINGKATAN MUTU PENDIDIKAN DI PONDOK PESANTREN
}

\author{
Eri Purwanti, Nurhadi Kusuma, Ruly Nadian Sari \\ Jl. Raya Wonokriyo Gadingrejo Pringsewu \\ Email: stitpringsewu@gmail.com
}

\begin{abstract}
The purpose of this study is to know the implementation of strategic management in an effort to improve the quality of education in Pondok Pesantren. This research use descriptive, analytic, qualitative method by using field study (field research) in data collection. From the results of research can be concluded: the implementation of strategic management in an effort to improve the quality of education in Pondok Pesantren, has been done well. Efforts to improve the quality of education in boarding schools increased and directed, because the implementation of strategic management made in boarding school can be implemented and the goal is achieved well.
\end{abstract}

\begin{abstract}
Abstrak
Tujuan penelitian tersebut adalah ingin mengetahui penerapan manajemen strategis dalam upaya peningkatan mutu pendidikan di Pondok Pesantren. Penelitian ini menggunakan metode deskriptif, analitik, kualitatif dengan menggunakan studi lapangan (field research) dalam pengumpulan data. Dari hasil penelitin dapat disimpulkan: penerapan manajemen strategis dalam upaya peningkatan mutu pendidikan di Pondok Pesantren, sudah terlaksana dengan baik. Usaha kegiatan peningkatan mutu pendidikan di pondok pesantren semakin meningkat dan terarah, karena penerapan manajemen strategis yang dibuat di pondok pesantren dapat dilaksanakan dan tujuannya tercapai dengan baik.
\end{abstract}

Kata Kunci: Manajemen Strategis, Peningkatan Mutu 


\section{A. PENDAHULUAN}

Pondok pesantren mempunyai peranan yang besar dalam dunia pendidikan, terutama dalam pendidikan Islam.Untuk mencetak generasi penerus yang cerdas dan berakhlak mulia diperlukan pendidikan yang menyeluruh, dalam arti mencakup semua potensi baik dari aspek kognitif, afektif, dan psikomotor.

Pondok pesantren adalah perpaduan dua kata yang dirangkaikan menjadi satu terdiri dari kata Pondok dan Pesantren.Sampai saat ini masih ada perbedaan pendapat mengenai asal - usul tentang pondok pesantren yaitu, ada yang mengatakan berasal dari India (Hindu) dan ada pula yang mengatakan berasal dari Arab. Mastuhu juga mendefinisikan pesantren adalah lembaga pendidikan tradisional Islam untuk mempelajari, memahami, menghayati, dan mengamalkan ajaran agama Islam dengan menekan pentingnya moral keagamaan sebagai pedoman perilaku sehari - hari untuk mencetak generasi penerus yang cerdas dan berakhlakul mulia dalam mencapai semua itu, maka perlu adanya manajemen pendidikan di pondok pesantren. Sistem pendidikan yang diterapkan di pondok pesantren nurul huda yaitu dengan sistem klasikal dan dipadukan dengan pendidikan modern karena didalam pondok pesantren nurul huda ada pendidikan formal dari tingkat Madrasah Tsanawiyah, Madrasah Aliyah dan Sekolah Menengah Kejuruan Nurul Huda dan pendidikan nonformalnya Madrasah Diniyah. Di Pondok pesantren nurul huda selain santri bisa belajar ilmu agama dan umum para santri juga dididik seni, seperti hadroh, music keroncong, pagar nusa (PN), kaligrafi, pidato tiga bahasa, pelatihan manasik haji dan umroh dan tilawah alQur'an.

Setiap lembaga pendidikan, baik pendidikan formal atau pun non formal pasti bertujuan untuk mengembangkan peserta didiknya kearah yang lebih baik, salah satu cara agar tujuan tersebut dapat tercapai adalah dengan melaksanakan manajemen pendidikan yang berkualitas dalam suatu lembaga pendidikan. Pondok pesantren sebagai salah satu lembaga pendidikan non formal juga menerapkan manajemen pendidikan agar peserta didik (santri) yang belajar di pondok tersebut dapat berkembang secara maksimal baik dari aspek kognitif, afektif, dan psikomotorik.Tidak mungkin lembaga pendidikan itu mengeluarkan lulusan yang baik apabila manajemennya dalam suatu pondok tersebut tidak baik pula.

Secara harfiah, manajemen strategis terbangun dari dua kata, yaitu manajemen dan strategis. Kata manajemen diartikan sebagai proses pemahaman sumber daya secara efektif untuk mencapai sasaran yang telah ditentukan.

Manajemen merupakan kemampuan dan keterampilan khusus untuk melakukan suatu kegiatan, baik bersama orang lain atau melalui orang lain dalam mencapai tujuan organisasi.

Strategis berawal dari kata strategi yakni rencana. Jadi, manajemen strategis merupakan serangkaian keputusan dan tindakan manajerial yang menentukan kinerja perusahaan dalam jangka panjang.

Prawirosentono dan Primasari (2014) memberikan pendapatnya bahwa manajemen starategi adalah ilmu dan seni untuk menyinergikan berbagai sumber daya yang dimiliki organisasi secara proporsional sehingga dapat diambil rangkaian keputusan strategik untuk mencapai tujuan organisasi secara optimum dengan memperhatikan lingkungan hidup. Menurut Siagian (2012), manajemen strategik adalah rencana berskala besar yang berorientasi jangkauan masa depan yang jauh serta ditetapkan sedemikian rupa sehingga memungkinkan organisasi berinteraksi secara efektif dengan lingkungannya dalam kondisi persaingan yang kesemuanya diarahkan pada optimalisasi pencapaian tujuan dan berbagai sasaran organisasi yang bersangkutan.

Manajemen strategik merupakan pendekatan sistematis untuk memformulasikan, mewujudkan, dan memonitoring strategi. Dan merujuk pada proses manajerial untuk membentuk visi strategi, penyusunan objektif strategi dan pelaksanaannya. Berdasarkan hal tersebut, jelas bahwa manajemen strategik tidak dapat lepas dari fungsi manajemen dimana sebelum sesuatu dijalankan terlebih dahulu harus ada perencanaan, pelaksanaan, dan evaluasi yang merupakan tahap yang harus dilakukan sebelum manajemen strategik dirumuskan guna mencapai suatu tujuan dengan mutu yang maksimal.

Mutu berkenaan dengan penilaian bagaimana suatu produk memenuhi kriteria standard atau rujukan tertentu. Rumusan mutu pendidikan bersifat dinamis dan dapat ditelaah dari berbagai sudut pandang. Sagala (2013) berpendapat bahwa mutu pendidikan adalah gambaran atau karakteristik menyeluruh jasa pelayanan jasa pelayanan pendidikan secara internal maupun eksternal yang menunjukkan kemampuannya memuaskan kebutuhan yang diharapkan atau yang tersirat mencakup input, proses dan output pendidikan. Priansa (2014) menyatakan bahwa upaya peningkatan mutu dalam pendidikan difokuskan kepada mutu proses pendidikan. Inti dari proses pendidikan adalah pembelajaran peserta didik. Proses pembelajaran ini mencakup sejumlah unsur utama yang mendasar yang membentuk mutu pembelajaran. Unsur-unsur tersebut adalah tujuan pembelajaran, isi kurikulum, guru, sarana dan prasarana, dana, manajemen dan evaluasi. Tujuan penting yang diperlukan dalam peningkatan mutu adalah ketepatan dan kejelasannya.

Berdasarkan penjelasan di atas maka tulisan ini membahas hasil penelitian yang berfokus 
kepada implementasi manajemen stratejik dalam upaya peningkatan mutu pendidikan pada pondok pesantren Nurul Huda Pringsewu. Implementasi strategik dalam manajemen sekolah atau pondok pesantren melibatkan upaya besar yang bertujuan mentrasformasi tujuan strategik ke dalam aksi dalam penyelenggaraan program kerja sekolah atau pondok pesantren. Betapapun hebatnya suatu strategi, apabila tidak diimplementasikan tentu saja strategi itu tidak akan bermakna bagi pengembangan sekolah atau pondok pesantren.

Gluck, dkk dalam penelitiannya mengusulkan bahwa sebagai manajer puncak dalam menghadapi dunia, manajemen strategis merupakan cara untuk mengelola semua sumber daya guna mengembangkan keunggulan kompetitif dan membantu menciptakan kesuksesan di masa yang akan datang.

Manajemen strategis merupakan suatu proses yang dinamika karena ia berlangsung terus menerus dalam suatu organisasi atau lembaga. Setiap strategi selalu memerlukan peninjauan ulang dan bahkan mungkin perubahan dimasa depan. Salah satu alasan utama mengapa demikian halnya ialah karena kondisi yang dihadapi oleh suatu organisasi, baik yang sifatnya internal maupun eksternal selalu berubah - ubah pula. Dengan perkataan lain strategis manajemen dimaksudkan agar organisasi menjadi satuan yang mampu menampilkan kinerja tinggi karena organisasi yang berhasil adalah organisasi yang tingkat efektivitas dan produktivitasnya makin lama makin tinggi. Hanya dengan demikianlah tujuan dan berbagai sasarannya dapat tercapai dengan hasil yang memuaskan.

Mengkaitkan manajemen strategis dengan upaya mencapai keunggulan bersaing, bahkan dikatakan bahwa strategis adalah alat penting dalam rangka mencapai keunggulan dalam bersaing. Hal tersebut sejalan dengan tujuan strategis yaitu untuk mempertahankan atau mencapai suatu posisi keunggulan dibandingkan dengan pihak pesaing. Implikasi dari kajian tersebut dikatakan masih meraih suatu keunggulan apabila ia dapat memanfaatkan peluang - peluang dari lingkungannya, yang memungkinkan organisasi untuk menarik keuntungan - keuntungan dari bidang yang menjadi kekuatan.

Dengan demikian, sekolah sebagai salah satu pusat pelaksana kegiatan pendidikan merupakan lembaga terstruktur yang memiliki peran dalam meningkatkan mutu pendidikan. Sekolah sebagai institusi mikro yang berperan langsung dalam mencetak generasi Indonesia yang berkualitas, sudah seharusnya memperoleh perhatian besar dari pemerintah dan masyarakat.

Sekolah atau pondok pesantren akan berfungsi dengan maksimal jika didukung oleh sistem manajemen yang terencana dan didukung oleh sumber daya manusia guru atau ustadz yang berkualitas, sarana -prasarana serta dana atau biaya pendidikan yang tepat. Penerapan peraturan dan sistem manajeman yang baku dalam lembaga pendidikan tentunya sangat dibutuhkan dalam upaya pemaksimalan potensi sekolah sehingga tercipta pendidikan yang bermutu.Tercapainya kesesuaian antara lingkungan, sekolah dan strategik, struktur serta proses sekolah, berpengaruh positif terhadap kinerja guru. Dengan melihat unsur pekerjaan manajemen strategik mengenai pemanfaatan sumber daya manusia, maka timbullah kelompok manusia yaitu manajemen strategik yang berkaitan dengan pendayagunaan sumber daya manusia dalam melakukan kinerja guru untuk jangka panjang dengan menggunakan strategik yang efektif dan efesien.

Guru atau ustadz sebagai orang kedua dalam kegiatan pembelajaran tidak terlepas dari adanya prinsip - prinsip belajar ini. Guru atau ustadz sebagai penyelanggara dan pengelolah kegiatan pembelajaran terimpilikasi oleh adanya prinsipprinsip belajar ini. Implikasi prinsip- prinsip belajar bagi guru tertampak pada rencana pembelajaran maupun pelaksanaan kegiatan pembelajarannya. Implikasi prinsip - prinsip belajar bagi guru terwujud dalam prilaku fisik dan psikis mereka. Kesadaran adanya prinsipprinsip belajar yang terwujud dalam prilaku guru atau ustadz, dapat diharapkan adanya peningkatan kualitas dan kinerja pembelajaran guru atau ustadz yang diselenggarakan. Selanjutnya, Tilaar, mengemukakan bahwa krisis pendidikan yang

dihadapi bangsa Indonesia ini berkisar pada krisis manajemen, di mana manajemen pendidikan merupakan mobilisasi segala sumber daya pendidikan untuk mencapai tujuan pendidikan yang ditetapkan. Sehingga Guru atau ustadz harus menyadari bahwa keaktifan membutukan keterlibatan langsung siswa ataupun santri dalam kegiatan pembelajaran. Namun demikian, perlu diingat bahwa keterlibatan langsung secara fisik tidak menjamin keaktifan belajar. Untuk melibatkan siswa secara fisik, mental - emosional, dan intelektual dalam pembelajaran, maka guru atau ustadz hendaknya merancang dan melaksanakan kegiatan pembelajaran dengan mempertimbangkan karakteristik siswa dan karakteristik isi pelajaran.

Dalam mewujudkan suatu pendidikan yang bermutu tentunya dibutuhkan suatu manajemen yang baik. Manajemen yang baik itu tentu mengacu pada fungsi - fungsi manajemen itu sendiri, dimana mencakup semua kegiatan yang dijalankan oleh institusi pendidikan, khususnya satuan pendidikan pada berbagai tingkatan dan fungsi tugasnya dalam rangka mencapai tujuan. Pada bagian ini pembahasan difokuskan pada implementasi fungsi perencanaan, 
pengorganisasian, penggerak (Actuiting), pengoordinasian, pengarahan dan pengawasan dan pemantauan.

Berdasarkan beberapa teori diatas dapat disimpulkan bahwa manajemen strategik pendidikan sangat erat kaitannya dengan peningkatan profesionalitas guru atau ustadz di suatu lembaga pendidikan, khususnya pada peningkatan profesionalitas guru atau ustadz. Dalam hal ini perkembangan pondok sangat memprioritaskan peningkatan mutu pendidikan yakni: peningkatan mutu guru atau ustadz melalui pendidikan akademik sesuai dengan visi dan misi sekolah dan peningkatan mutu penyelenggaraan program yang ada di sekolah.

Untuk itu, dalam melaksanakan tugas profesinya, guru dihadapkan pada berbagai pilihan, seperti: cara bertindak yang paling tepat, bahan belajar yang paling sesuai, metode penyajian yang paling efektif, alat bantu yang paling cocok, langkah - langkah yang paling efesien, sumber belajar yang paling lengkap, sistem evaluasi apa yang paling tepat dan sebagainya. Sebagai pelaksana tugas otonom, guru diberi keleluasan untuk mengelola pembelajaran. Guru atau ustadz harus dapat menentukan pilihannya dengan mempertimbangkan semua aspek yang relevan atau menunjang tercapainnya tujuan. Dalam hal ini guru atau ustadz bertindak sebagai pengambil keputusan. Menyikapi hal tersebut khususnya di pondok pesantren nurul huda yang telah berupaya memposisikan diri dan bersaing khususnya dengan pondok lainnya, dengan menerapkan manajeman strategik yang merupakan salah satu unsur pendidikan yang memiliki andil dalam peningkatan profesionalitas guru atau ustadz. Namun dalam penyusunan dan pelaksanaan manajemen tersebut, timbul berbagai masalah yang sangat berpengaruh terhadap optimalnya tujuan pendidikan yang ingin di capai.

Mutu Pendidikan Secara umum, mutu adalah gambaran dan karakteristik menyeluruh dari barang atau jasa yang menunjukkan kemampuannya dalam memuaskan kebutuhan yang diharapkan atau yang tersirat. Dalam konteks pendidikan, pengertian mutu mencakup input, proses dan output pendidikan.

Pondok Pesantren Pondok berarti bangunan tempat tinggal yang berpetak-petak, rumah asrama. Sedangkan Pesantren berarti asrama atau tempat santri, murid-murid belajar mengaji.

Sudjoko Prasodjo dkk, mendefinisikan pesantren sabagai suatu lembaga pendidikan Islam di Indonesia, untuk mendalami ilmu agama Islam dan mengamalkannya sebagai pedoman hidup keseharian dengan menekankan pentingnya moral dalam bermasyarakat.

Adapun pondok pesantren disini adalah kompleks psantren yang terdiri dari asrama untuk tempat tinggal para santri yang datang dari jauh dan tinggal di dalamnya untuk memperdalam ilmu-ilmu agama. Manajemen sering diartikan sebagai ilmu, karena manajemen dipandang sebagai suatu bidang pengetahuan yang secara sistematis berusaha

memahami mengapa dan bagaimana orang yang bekerjasama yang dilandasi oleh keahlian khusus untuk mencapai prestasi kerja.

Menurut Gluck, dkk dalam penelitiannya mengusulkan bahwa sebagai manajer puncak dalam menghadapi dunia, manajemen strategis merupakan cara untuk mengelola semua sumber daya guna mengembangkan keunggulan kompetitif dan membantu menciptakan kesuksesan di masa yang akan datang.

Tercapainya kesesuaian antara lingkungan organisasi dan strategi, struktur serta proses organisasi, berpengaruh positif terhadap kinerja organisasi. Dengan melihat unsur pekerjaan manajemen strategis mengenai pemanfaatan sumber daya manusia, maka timbul kelompok manusia yaitu manajemen strategis yang berkaitan dengan pendayagunaan sumber daya manusia dalam melakukan kinerja untuk jangka panjang dengan menggunakan manajemen strategis yang mutakhir, efektif, dan efesien.

Dalam upaya meningkatkan mutu adalah gambaran dan karakteristik menyeluruh dari bidang atau jasa yang menunjukkan dalam kemampuan memuaskan kebutuhan yang diharapkan atau tersirat. Dalam konteks pendidikan, pengertian mutu mencakup input, proses, dan output pendidikan.

Gerak pembangunan nasional atau tantangan dewasa ini telah berada pada suatu era "modern". Era tersebut ditandai dengan kemajuan ilmu pengetahuan dan teknologi begitu pula dalam pemanfaatannya. Hal ini

memicu lahirnya penerapan manajemen strategis dalam upaya peningkatan mutu pendidikan di pondok pesantren yang semakin menuntut untuk keahlian dan kekhususan dalam menanganinya, dan menempatkan era ini sebagai era sumber daya manusia. Untuk itu, meningkatkan kualitas lembaga pendidikan dibutuhkan sumber daya manusia yang memiliki kemampuan yang relevan dengan kebutuhan perencanaan pendidikan.

Tantangan yang sama juga terjadi pada pesantren, yang mana kita tahu bahwa pesantren adalah lembaga pendidikan Islam tertua di Indonesia.

Maka dalam hal ini perlu ada pengembangan dan pembaharuan, agar pesantren tidak ketinggalan zaman. Akan tetapi dalam mengembangkannya tetap memegang prinsip. "Al-Muhafadzatu 'Ala al-Qodimi As-Shalih wal Akhdzu bil-Jadid al-Ashlah", yaitu mempertahankan tradisi lama yang masih relevan dan mengambil ide baru yang konstruktif dan prospektif, harus dipegang dan dikembangkan. Hal ini perlu secara serius 
menggabungkan mainstream (tradisional dan modern) dengan sama-sama kuat, dengan gradulasi dan stratifikasi sinergis dan strategis.

Pergerakan pesantren adalah lembaga pendidikan yang bertujuan untuk membangun dan membina para pendidik untuk melakukan dakwah islamiyah dengan mempersiapkan generasi muda muslim dengan membekali mereka pengetahuan agama dan umum. Lembaga pendidikan adalah salah satu media penting yang dapat membentuk bagaimana corak pandangan hidup seseorang atau masyarakat, apakah pandangan hidup mereka hanya untuk kepentingan di dunia ini saja atau untuk akherat saja atau untuk keduanya. Selain hal itu, lembaga pendidikan dapat membentuk manusia yang cerdas, bermoral, memiliki semangat hidup dan memiliki semangat mengembangkan ilmu dan teknologi guna membangun bangsanya.

Pondok Pesantren Nurul Huda merupakan salah satu pesantren yang bisa dikategorikan pesantren modern. Pondok pesantren Nurul Huda membagikan tugas kelembagaan lebih rinci dan disesuaikan dengan profesi perseorangan yang duduk di personalia lembaga. Lembaga pondok pesantren terikat oleh nilai dan norma misi kelembagaan Nurul Huda yang termuat garis besar Khitkhah Trisula, yaitu suatu rangkuman nilai dan norma menjadi misi pendidikan Nurul Huda. Nilai tersebut bersumber dari nilai-nilai yang berada di lembaga pendidikan Pondok Pesantren Nurul Huda lebih meningkatkan profesionalisme dalam peningkatan mutu pendidikan yang dimiliki oleh Nurul Huda.

Adapun dari beberapa pesantren yang sudah banyak mengadakan perubahan-perubahan yang mendasar sebagai jawaban positif atas perkembangan ini, namun perubahan tersebut masih sangat terbatas. Ada 2 alasan utama yang menyebabkannya, yaitu: 1. para kyai masih harus mempertahankan dasar-dasar tujuan pendidikan pesantren, yaitu bahwa pendidikan pada dasarnya ditunjukan untuk mempertahankan dan menyebarkan Islam, dan 2. mereka belum memiliki staf sesuai dengan kebutuhan pembaharuan untuk mengajarkan cabang-cabang pengetahuan.

Maka yang dilakukan oleh pengasuh pondok pesantren Nurul Huda untuk menyediakan fasilitas yang sempurna bagi santri pondok pesantren, apabila kelak harus terjun ke masyarakat merupakan kelanjutan pondok pesantren atas tantangan masyarakat lingkungannya. Maka dari itu, manajemen strategis di Pondok Pesantren mempunyai keputusan dan tindakan yang mengarah sesuai dengan watak dan perilaku yang sistematis, terencana dan terarah.

Adapun faktor-faktor kualitas dan mutu yang dimaksud adalah sumber daya manusia yang ada di pondok pesantren tersebut, yang meliputi pengurus pesantren (kiai), pengajar (ustadz) dan pendidik (santri). Menyimak dari faktor-faktor diatas, perkembangan pesantren hendaknya memperioritaskan peningkatan mutu pendidikan, yakni: Peningkatan mutu guru pesantren melalui pendidikan akademik dan profesional, mengembangkan kurikulum secara berkelanjutan sesuai dengan visi dan misi pesantren, dan peningkatan mutu penyelenggaraan program yang ada di pesantren.

Maka dari itu, pengasuh pondok pesantren Nurul Huda harus mengembangkan potensi santri untuk memperoleh kecakapan hidup melalui lembaga pendidikan. Maka diharapkan lembaga pendidikan dapat memberikan fasilitas yang memadai serta dapat memberdayakan santrinya agar output yang diharapkan tercapai. Untuk para santri harus menyadari bahwa dalam mengembangkan potensi dirinya tidak harus mengharapkan dalam pendidikan pondok pesantren saja.

Adapun unsur-unsur yang mempengaruhi kualitas dan mutu pendidikan adalah sumber daya manusia yang ada di pondok pesantren tersebut, yang meliputi pendiri pesantren (bapak pengasuh), pelaksana dan ustadz/ah, pelajar (santri) yang secara pribadi langsung diajar berdasarkan naskah-naskah Arab Klasik tentang pengajaran, faham dan akidah ke Islaman.

Sebaiknya hal tersebut mampu memprioritaskan peningkatan mutu pendidikan, yakni: peningkatan mutu guru pesantren melalui pendidikan akademik dan non akademik, mengembangkan kurikulum secara berkelanjutan sesuai dengan visi dan misi pesantren, dan peningkatan mutu penyelenggaraan program yang ada di pesantren.

Maka dari itu, Pengasuh Pondok Pesantren menurut Wahid Hasyim harus mampu mengembangkan potensi santri untuk memperoleh kecakapan hidup melalui lembaga pendidikan. Sehingga diharapkan lembaga pendidikan dapat memberikan fasilitas yang memadai agar dapat memberdayakan santri dengan output yang sesuai dengan visi serta misi bersama secara efektif dan efisien.

Bagi para santri tentunya harus menyadari pula bahwa dalam mengembangkan potensi dirinya sangat diperlukan keinginan kuat dari dalam dirinya masing-masing serta dukungan dari orang tua.

Kaitannya dengan mutu pendidikan, apakah pesantren menggunakan standar Total Quality Management untuk menjadikan pendidikan yang berorientasi pada mutu.

Total Quality Management dalam pendidikan berarti penerapan manajemen strategis yang bersifat total pada seluruh komponen, dimana didalamnya meliputi Quality Assurance dan Quality Control. Berdasarkan penjelasan diatas, maka penulis tertarik untuk melakukan penelitian dengan judul "Implementasi Manajemen Strategis Dalam 
Upaya Peningkatan Mutu Pendidikan Di Pondok Pesantren Nurul Huda Pringsewu". Penelitian ini terfokus pada penerapan manajemen strategis dalam peningkatan mutu pendidikan di Pondok Pesantren Nurul Huda Pringsewu.

Salah satunya penerapan manajemen strategis di pondok pesantren. Dengan penelitian ini diharapakan untuk mengetahui tingkat keberhasilan dalam pencapaian serangkaian tujuan dan dari segi bentuk evaluasi terhadap pelaksanaan perencanaan peningkatan mutu pendidikan di pondok pesantren yang telah ditetapkan.

\section{B. TUJUAN PENELITIAN}

Tujuan yang ingin dicapai dalam penelitian ini adalah: Untuk mengetahui penerapan manajemen strategis dalam upaya peningkatan mutu pendidikan yang diterapkan di Pondok Pesantren Nurul Huda Pringsewu.

\section{METODE PENELITIAN}

Penelitian ini termasuk dalam penelitian lapangan (field reseach), yaitu kegiatan penelitian yang dilakukan dilingkungan tertentu dalam hal ini akan dilakukan di pondok pesantren Nurul Huda Pringsewus. Guna mendapatkan data yang sesuai dengan permasalahan yang dibahas.

Dalam penelitian ini menggunakan pendekatan kualitatif dengan pertimbangan: Penelitian ini bertujuan mendapatkan gambaran yang menjelaskan tentang input, proses dan output dalam implementasi manajemen strategis dalam upaya peningkatan mutu pendidikan di podok pesantren Nurul Huda Pringsewu.

Data yang disusun dikumpulkan tidak memungkinkan disusun, diubah dan dianalisis dengan menggunakan data-data yang diperoleh dari lapangan.

\section{HASIL DAN PEMBAHASAN}

\section{Penyusunan Rencana Strategis untuk meningkatkan mutu pendidikan pada pondok pesantren Nurul Huda Pringsewu.}

Hasil wawancara dengan pengasuh pondok pesantren Nurul Huda Pringsewu memberi informasi bahwa pengasuh melibatkan pihakpihak terkait dalam perencanaan strategis dengan formulasi penyusunan meliputi rencana jangka pendek, rencana jangka menengah, dan rencana jangka panjang. menganalisis kebutuhan dan menyusun program pondok sesuai dengan ketentuan yang berlaku, dan juga mensosialisasikannya kepada mereka yang akan terlibat dalam implementasi program kerja tersebut. Hal ini menunjukkan bahwa pengasuh pondok pesantren Nurul Huda selalu bersifat transparan dalam melaksanakan tugasnya. Hasil analisis dokumentasi juga menunjukkan bahwa pengasuh pondok pesantren Nurul Huda memiliki program kerja dengan rumusan sasaran program peningkatan antara lain : 1) rata-rata NEM (Nilai Evaluasi Murni) mencapai minimal 7,2 ) persentase kelulusan/tamatan yang diterima di Sekolah Menengah favorit atau unggul yang tersebar di seluruh provinsi Lampung maupun di luar provinsi, 2) memiliki program tahfizh AlQur'an yang merupakan program unggulan dan telah mampu mengantarkan siswanya menjadi juara tingkat Nasional, 3) Memiliki team olah raga dan team kesenian yang dapat tampil di tingkat provinsi, 4) menciptakan sekolah menjadi sekolah islami dan berseri (bersih, sejuk, elok, rindang, dan indah), 5) Menciptakan lingkungan atau suasana belajar di kelas yang nyaman dan tertib, 6) semua siswa meningkatkan kegiatan keagamaan secara benar dan jujur, 7) menciptakan kegiatan administrasi sekolah dan pondok yang efektif dan efisien, dan 8) menyusun program-program unggulan seperti; Islamic Camp, kegiatan Ekstrakurikuler, Kunjungan Edukatif, Outbound, motivation training, rihlah, mabit, mentoring, dan OMOB (One Month One Book). Program yang disusun merupakan program kerja Kepala Sekolah dan pengasuh pondok yang menjadi rujukan Kepala Sekolah dan pengasuh pondok dalam melaksanakan penyusunan rencana strategis untuk meningkatkan mutu pendidikan pada pondok pesantren Nurul Huda.

\section{Pelaksanaan atau Proses Rencana Strategis dalam Rangka Meningkatkan Mutu Pendidikan pada pondok pesantren Nurul Huda.}

Tahap awal yang dilakukan dalam manajemen strategis untuk meningkatkan mutu pada pondok pesantren Nurul Huda adalah menganalisis faktor internal dan faktor eksternal. Faktor internal berupa analisis kekuatan dan kelemahan, sedangkan faktor eksternal berupa analisis peluang dan tantangan. Pengasuh dan kepala sekolah pondok pesantren Nurul Huda telah melakukan serangkaian implementasi strategis secara sistimatis dan terpadu, antara lain: 1) penerapan kurikulum, 2) peningkatan mutu pendidik dan tenaga kependidikan, 3) peningkatan mutu peserta didik, 4) peningkatan kompetensi kelulusan, 5) peningkatan manajemen sarana prasarana sekolah, 6) pemenuhan standard pembiayaan, dan 7) pemenuhan standar penilaian. Berdasarkan keseluruhan data yang telah disajikan di atas disimpulkan bahwa: pelaksanaan rencana stratejik dalam upaya peningkatan mutu pendidikan oleh Kepala sekolah dan pengasuh pondok pesantren Nurul Huda telah berjalan 
dengan baik, efektif dan efisiesi, dan diyakini mengalami peningkatan yang signifikan.

\section{Evaluasi dari Implementasi Manajemen Strategis pada pondok pesantren Nurul Huda dalam Peningkatan Mutu Pendidikan.}

Hasil evaluasi dari implementasi strategis umumnya menunjukkan bahwa pelaksanaan rencana stratejik untuk meningkatkan mutu pendidikan pada pondok pesantren Nurul Huda telah dilaksanakan dengan baik. Namun hasil yang maksimal dalam arti mencapai mutu yang tinggi masih belum terwujud secara memuaskan, karena masih terjadi sejumlah hambatan dalam pelaksanaan implementasi rencana stratejik yang dilaksanakan oleh kepala sekolah dan pengasuh pondok. Berdasarkan hasil wawancara yang dilaksanakan dengan kepala sekolah dan pengasuh pondok diperoleh informasi bahwa setelah melakukan berbagai kegiatan atau pelaksanaan program yang telah disusun sesuai dengan visi, misi dan tujuan sekolah, maka sekolah perlu melakukan evaluasi dengan merefleksi hasil yang telah dicapai. Lebih lanjut kepala sekolah juga menambahkan bahwa evaluasi dapat juga dilakukan melalui observasi, supervisi, dan monitoring yang dilakukan oleh manajemen puncak sekolah dan evaluasi diri sekolah. Berdasarkan hasil wawancara di atas dengan didukung oleh studi dokumentasi yang penulis lakukan menunjukkan bahwa pondok pesantren Nurul Huda dievaluasi setiap bulan, semester, dan tahun. Evaluasi jangka pendek dilakukan setiap akhir semester untuk mengetahui keberhasilan program yang telah dijalankan secara bertahap sehingga dapat dilakukan tindakan korekif terhadap pelaksanaan program pada semerter tersebut. Evaluasi jangka menengah dilakukan pada akhir tahun ajaran guna mengetahui keberhasilan ketercapaian program yang dijalankan sesuai dengan harapan. Selanjutnya, evaluasi jangka panjang dilakukan setiap lima tahun sekali dengan melibatkan pihak ekternal sekolah seperti komite sekolah, yayasan sekolah, dan para stakeholder dalam upaya peningkatan mutu sekolah.

\section{E. PENUTUP}

\section{Kesimpulan}

Hasil penelitian menunjukkan bahwa pondok pesantren telah menerapkan manajemen strategis dalam upaya peningkatan mutu pendidikan, untuk itu dapat ditarik beberapa kesimpulan sebagai berikut:

1. Manajemen strategis di pondok pesantren merupakan peningkatan kualitas organisasi yang telah diterapkan sebelumnya untuk tercapainya suatu tujuan yang telah dilakukan pondok pesantren yang mempunyai landasan dasar dalam melakukan kriteria atau indikator - indikator untuk dapat disesuaikan ke masas yang akan datang dalam jangka panjang, mencakup: penetapan strategi, penerapan strategi, evaluasi - kontrol strategi.

2. Perencanaan mutu pendidikan di pondok pesantren Nurul Huda, mencangkup: (1) seleksi SDM, (2) Kurikulum, (3) Sarana dan prasarana, (4) penyetaraan pendidikan, (5) akuntabilitas pendidikan.

3. Pelaksanaan kinerja mutu di pondok pesantren memiliki sebuah lembaga yang menerapkan Total Quality Management (TQM) maka untuk menjamin kualitas yang dibutuhkan langkah - langkah (1) Quality Control (jaminan kualitas), dimana didadlamnya meliputi pendeteksian kegiatan - kegiatan yang ada di pondok pesantren Nurul Huda sebagai berikut: strategi fokus, self financing, out sourching, aliansi strategi, optimalisasi, dan simbiosis mutualisme. (2) Quality Assurance (kualitas yang dilakukan sebelum proses dan dalam proses pendidikan). (A) sebelum melakukan proses pendidikan, adapun seleksi yang diterapkan adalah: (1) tes akademik, (2) tes wawancara agama, (3) tes wawancara motivasi, adapun (B) dalam proses pendidikan memiliki 2 aspek dalam melakukan program di pondok pesantren Nurul Huda sebagai berikut: (1) metode pengajaran, dan (2) kemampuan ustadz.

\section{Saran}

Berdasarkan kesimpulan hasil penelitian yang berkaitan dengan implementasi manajemen strategis dalam upaya peningkatan mutu pendidikan di pondok pesantren Nurul Huda, maka manajemen strategis mempunyai peran multifungsi dalam peningkatan mutu pendidikan pesantren, antara lain sebagai berikut:

1. Diharapakan kepada pengurus Ponpes Nurul Huda untuk lebih mengembangkan pola manajerial strategisnya secara kreatif dan inovatif serta mengimplementasikanya secara lebih konsisten.

2. Untuk lebih meningkatkan kualitas atau mutu, baik pendidikan islam maupun umum, Ponpes Nurul Huda hendaknya menjadikan manajemen strategis sebagai pijakan dalam mengoptimalkan pelaksanaan program di semua lini.

\section{DAFTAR PUSTAKA}

Anisari, A., Purwanti, E., \& Masrur, M. (2017). Strategi Kepala Sekolah Dalam Meningkatkan Mutu Pembelajaran Di Smp Nurul Islam Kelurahan Garuntang 
Kecamatan Bumi Waras Kota Bandar Lampung. Jurnal Manajemen Pendidikan Islam Al-Idarah, 1(1), 1-9.

Apriyani, M. A., Purwanti, E., \& Al Mursyid, A. (2018). Implementasi Manajemen Kurikulum Dalam Meningkatan Mutu Pendidikan di SMP PGRI 1 Pulaupanggung, Kabupaten Tanggamus. Jurnal Manajemen Pendidikan Islam AlIdarah, 3(1), 42-48.

Kusuma, N., \& Purwanti, E. (2017). Pengaruh Kompetensi Pedagogik Dan Manajemen Pembelajaran Terhadap Penjaminan Mutu Pada Universitas Sang Bumi Ruwa Jurai Lampung. Indonesian Journal Of Educational Counseling, 1(2), 209-226.

Prawiroetono dan Primasari. (2014). Manajemen Strategik dan Pengambilan Keputusan korporasi, PT Bumi Aksara, Jakarta.

Priansa, (2014), Manajemen Supervisi dan kepemimpinan Kepala Sekolah. Alfabeta, Bandung.

Sagala, S. (2013). Manajemen Strategik dalam Peningkatan Mutu Pendidikan. Alfabeta, Bandung.

Siagian, S. P. (2012). Manajemen Strategik. Bumi Aksara, Jakarta. 